\title{
Study Treatment Course Completion Occurrence
}

National Cancer Institute

\section{Source}

National Cancer Institute. Study Treatment Course Completion Occurrence. NCI

Thesaurus. Code C83062.

An indication or description that the course of study treatment has been carried out in full. 